\title{
Synthesis and Characterization of Some NH-Analogues of Ciprofloxacin on Antibacterial, Antifungal, and Cytotoxic Activities
}

\author{
M. G. Rabbani ${ }^{1}$, M. R. Islam ${ }^{2}$ \\ ${ }^{1}$ Research and Development, Gonoshasthaya Antibiotic Ltd., Dhaka, Bangladesh \\ ${ }^{2}$ Department of Chemistry, Jahangirnagar University, Dhaka, Bangladesh
}

Received 27 August 2019, accepted in final revised form 24 February 2020

\begin{abstract}
Present work includes synthesis of five NH-analogues of ciprofloxacin, 2-6 have been prepared to find out their medicinal assessment, for instance, antibacterial, antifungal, and cytotoxicity. The structure of the analogues has been confirmed by FT- IR, ${ }^{1} \mathrm{H}-\mathrm{NMR},{ }^{13} \mathrm{C}-$ NMR, mass spectral data and elemental analysis. The compounds were screened for their antimicrobial activities by the disc diffusion method. Cytotoxicity was also tested against brine shrimp lethality assay. The antimicrobial activity of the analogues compared with the parent was evaluated against three Gram-positive, five Gram-negative bacterial strains and three fungi. The synthesized compounds showed diverse antimicrobial profile among which derivatives, $\mathbf{2}$ and $\mathbf{3}$ possessed enhanced activity in contrast to the ciprofloxacin. Additionally, unlike ciprofloxacin, most of the derivatives were also found to show antifungal activity against Candida albicans. Regarding cytotoxicity, most of the derivatives exhibited better cytotoxic activity than ciprofloxacin.
\end{abstract}

Keywords: Ciprofloxacin derivatives; Antibacterial; Antifungal; Cytotoxicity.

(C) 2020 JSR Publications. ISSN: 2070-0237 (Print); 2070-0245 (Online). All rights reserved.

doi: http://dx.doi.org/10.3329/jsr.v12i3.42804 J. Sci. Res. 12 (3), 349-362 (2020)

\section{Introduction}

Ciprofloxacin, $\mathbf{1}$ is a synthetic antibacterial related to nalidixic acid having a fluorine atom and piperazine ring at positions 6 and 7 of quinolone-3-carboxylic acid. Ciprofloxacin, first introduced in 1987, is a second-generation broad spectrum and one of the most widely used, belongs to fluoroquinolones antibiotic. Quinolones realize their effect by converting gyrases and topoisomerases IV into toxic enzymes that fragment bacterial chromosome [1-5]. Ciprofloxacin impedes the replication and transcription of bacterial DNA, leading to an increase in oxidative stress and death of bacterial cells [6]. According to the World Health Organization, it is one of the most frequently prescribed antimicrobial drugs [7]. Ciprofloxacin has been permitted to treat a lot of Gram-positive and Gram-

\footnotetext{
Corresponding author: rabbani_golam07@yahoo.com
} 
negative bacterial infections [8-12]. It has a well-known anti-tumor activity against P388 leukemia [13]. Structure-activity-relationship (SAR), mechanism of action, resistance and clinical aspects of some fluoroquinolones antibacterial activity has been reported [14]. A series of nadifloxacin derivatives has been synthesized and were found to show activity against hospital infections of multi-drug-resistance and vancomycin-resistant Staphylococcus aureus [15]. $\mathrm{COOH}$ group of ciprofloxacin converted into its amide and ester derivatives and found diverse antimicrobial profile [16]. Modifications of ciprofloxacin skeletal and antimicrobial action have been studied, where some of its derivatives possessed antifungal properties [17]. Ciprofloxacin has been incorporated into a new series of Schiff base of 1,2,4-triazole via Mannich reaction and got comparable antibacterial results with ciprofloxacin [18]. NH-derivatives of ciprofloxacin have been prepared and showed enhanced activities against Gram-negative bacteria compared to ciprofloxacin [19]. Metal complexes continue a significant resource for creating a chemical range in the fields of pharmaceutical chemistry as antitumor and antimicrobial agents and are permitted to treat with drug-resistant bacteria and a range of viral diseases [20-24]. Earlier we produced ciprofloxacin- $p$-nitro benzoyl derivative, and its transition metal complexes for biological evaluation. The compounds showed diverse antimicrobial profile amongst which most compounds possessed a comparable or better activity in comparison to the ciprofloxacin and some of the derivatives were also found to demonstrate antifungal property [25]. Most of the ciprofloxacin biological research has been focused on the functionality at the $\mathrm{C}-7$ position or other functional groups but the SAR reveals that the C-7 substituent is the most adaptable site for chemical change and is an area that determines the strength and target predilection. An initiative has been taken to substitute the $\mathrm{H}$-atom of the $\mathrm{NH}$ group of the piperazine moiety of ciprofloxacin with $\mathrm{N}$ methylpyrrolidone, camphor, 1-cyanoguanidine, 1-cyanonaphthalene, and dimethylsulfate respectively to obtain derivatives 2-6 for biological evaluation (Scheme 1).

In the present study, the synthesis, structure conformation and evaluation of biological activities, i.e., antibacterial, antifungal and cytotoxicity of some ciprofloxacin derivatives will be reported.

\section{Materials and Methods}

\subsection{General}

Gonoshasthaya Antibiotic Ltd, Savar, Dhaka, Bangladesh gifted ciprofloxacin hydrochloride. All the synthetic works were carried out by using laboratory reagents and analytical grade solvents whenever necessary. The solvents and reagents were purified and dried according to a standard procedure. The progress of all reactions was monitored by TLC, which was performed on aluminum sheets pre-coated with silica gel 60F254 to a thickness of $0.25 \mathrm{~mm}$ (Merck, Germany). The mobile phase was acetonitrile: conc. $\mathrm{NH}_{3}$ solution: $\mathrm{CH}_{3} \mathrm{OH}: \mathrm{CH}_{2} \mathrm{Cl}_{2}$ (10: 20: 40: 40). The chromatograms were visualized under ultraviolet light, $254 \mathrm{~nm}$ or iodine vapors. The purity of the compound was examined by 
HPLC on an LC-20 AT liquid chromatography equipped with UV detector SPD-20A at $278 \mathrm{~nm}$ and column oven CTO-10ASvp, using a mobile phase of acetonitrile and phosphoric acid (2.45 g/L solution) in the ratio $13: 87$ and $\mathrm{pH}$ adjusted at required $\mathrm{pH} 3.0$ with triethylamine. HPLC column was $250 \times 4.6 \mathrm{~mm}$ length with $10 \mu \mathrm{L}$ injection system. The column temperature was maintained at $40{ }^{\circ} \mathrm{C}$ during analysis, with a flow rate of 1.5 $\mathrm{mL} / \mathrm{min}$. The compounds were purified by recrystallization using suitable solvents. The melting points of the synthesized compounds were determined in open capillaries using Veego VMP-1 apparatus and expressed in ${ }^{\circ} \mathrm{C}$ and were uncorrected. The IR spectra of the compounds were recorded on a Shimadzu FT-IR-8400s spectrometer using $\mathrm{KBr}$ pellet technique. ${ }^{1} \mathrm{H}-\mathrm{NMR}$ and ${ }^{13} \mathrm{C}$ - NMR spectra were recorded on a Bruker DRX-400 (400 MHz FT-NMR) using dimethyl sulfoxide (DMSO) solvent and tetramethylsilane (TMS) as an internal standard. Mass spectra were obtained using a Shimadzu LC-MS (ESI) 2010A spectrophotometer. Either protonated ions $(\mathrm{M}+\mathrm{H})^{+}$or sodium adducts $(\mathrm{M}+\mathrm{Na})^{+}$ were used for empirical formula confirmation at the Department of Nano Fusion Technology, Organic Optoelectronic Material Lab., Pusan National University, South Korea. Elemental analyses (C, H, and N) were obtained using a Carlo Erba NA-1500 analyzer. The in vitro antimicrobial activities of the analogues were carried out by the disc diffusion method, and all the bacterial and fungal strains were collected as a pure culture from Vaccine Research Laboratory, Gonoshasthaya Kendra, Savar, Dhaka. Cytotoxicity measured by the brine shrimp lethality assay from the Department of Chemistry, Jahangirnagar University, Savar, Dhaka, Bangladesh.

\subsection{Regeneration of ciprofloxacin and synthesis of ciprofloxacin derivatives}

A solution of ciprofloxacin hydrochloride $(10 \mathrm{~g}, 27.19 \mathrm{mmol})$ in water $(50 \mathrm{~mL})$ was treated with $5 \%$ aqueous sodium carbonate solution at $\mathrm{pH}, 7.0$ resulting in the formation of white precipitates, filtered through suction filter and left to dry as a neutral ciprofloxacin, $1(8.2 \mathrm{~g}, 91 \%)$. These precipitates were used as starting material for all the reactions without purification. Generally, ciprofloxacin was converted to its enamine, cyanoguanidine, cyanonaphthalene, and $\mathrm{N}$-methylation derivatives by reaction with $\mathrm{N}$ methylpyrrolidone, camphor, 1-cyanoguanidine, 1-cyanonaphthalene, and dimethylsulfate respectively to obtain derivatives $\mathbf{2 - 6}$ (Scheme 1).

2.2.1. Reaction of ciprofloxacin with $N$-methyl pyrrolidone, 1-cyclopropyl-6-fluoro-7-(4(1-methyl-4, 5-dihydro-1H-pyrrol-2-yl) piperazin-1-yl)-4-oxo-1,4-dihydroquinoline-3carboxylic acid, 2 :

Ciprofloxacin $(1.5 \mathrm{~g}, 4.52 \mathrm{mmol})$ was dissolved in a mixture of methanol $(10.0 \mathrm{~mL})$ and dichloromethane $(5.0 \mathrm{~mL})$ to which equal ratio of $\mathrm{N}$-methyl-2-pyrrolidone $(0.448 \mathrm{~g}, 4.52$ mmol) was added with vigorous stirring. One drop of conc. $\mathrm{HCl}$ was added to make the solution clear. The reaction mixture was warmed at $40{ }^{\circ} \mathrm{C}$ with stirring for $90 \mathrm{~min}$ and organic solvents were removed by distillation. To the mixture was added $50 \mathrm{~mL}$ of water, 
after which the crystalline product deposited. It was collected by filtration, washed with $60 \%$ aqueous ethanol and dried under vacuum in a desiccator. The spectral data and other findings are given in section 3.1.1.<smiles>[R]N1CCN(c2cc3c(=O)c(C(=O)O)cn(C)c3cc2F)CC1</smiles><smiles>[R]=[Ni]=Cc1cccc2ccccc12</smiles>

Scheme 1. Synthesis of ciprofloxacin derivatives, $\mathbf{2 - 6}$ by alkylation reaction.

2.2.2. Reaction of ciprofloxacin with camphor, 1-cyclopropyl-6-fluoro-4-oxo -7-[4-(1, 7, 7-trimethyl -bicyclo [2.2.1] hept-2-en-2-yl)-piperazin-1-yl]-1, 4-dihydro-quinoline-3carboxylic acid, 3 :

Ciprofloxacin (1.5 g, $4.52 \mathrm{mmol})$ was dissolved in a mixture of methanol $(10.0 \mathrm{~mL})$ and dichloromethane $(5.0 \mathrm{~mL})$ to which equal ratio of camphor $(0.69 \mathrm{~g}, 4.52 \mathrm{mmol})$ was added with vigorous stirring. One drop of conc. $\mathrm{HCl}$ was added to make the solution clear. The reaction mixture was warmed at $40{ }^{\circ} \mathrm{C}$ with stirring for $90 \mathrm{~min}$ and organic solvents were removed by distillation. To the mixture was added $50 \mathrm{~mL}$ of water after which the crystalline product deposited. It was collected by filtration, washed with $60 \%$ aqueous ethanol and dried under vacuum in a desiccator. The spectral data and other findings are presented in section 3.1.2.

2.2.3. Reaction of ciprofloxacin with 1-cyanoguanidine, 1-cyclopropyl-6-fluoro-7-[4(guanidino-imino-methyl)-piperazin -1-yl]-4-oxo-1, 4-dihydro-quinoline-3-carboxylic acid, 4:

An equal proportion of ciprofloxacin $(1.00 \mathrm{~g}, 3.01 \mathrm{mmol})$ and 1 -cyanoguanidine $(0.254 \mathrm{~g}$, $3.02 \mathrm{mmol}$ ) were mixed and heated to $140-145^{\circ} \mathrm{C}$ to make a homogeneous mass. It was heated for an additional $10 \mathrm{~min}$ at the same temperature and allowed to cool at room temperature for solidification. $50 \mathrm{~mL}$ of water was added when yellow crystals deposited. It was filtered off, washed with $60 \%$ aqueous ethanol and dried under vacuum in a desiccator. The results are given in section 3.1.3. 
2.2.4. Reaction of ciprofloxacin with 1-cyanonaphthalene, 1-cyclopropyl-6-fluoro-7-(4(imino (naphthalen-1-yl) methyl) piperazin-1-yl)-4-oxo-1, 4-dihydroquinoline-3carboxylic acid, 5 :

An equal proportion of ciprofloxacin $(1.00 \mathrm{~g}, 3.01 \mathrm{mmol})$ and 1-cyanonaphthalene $(0.462$ $\mathrm{g}, 3.02 \mathrm{mmol}$ ) were mixed and heated to $140-145^{\circ} \mathrm{C}$ to make a homogeneous mass. It was heated for an additional $10 \mathrm{~min}$ at the same temperature and allowed to cool at room temperature for solidification. $50 \mathrm{~mL}$ of water was added when yellow crystals deposited. It was filtered off, washed with $60 \%$ aqueous ethanol and dried under vacuum in a desiccator. The spectral, physical, and others analytical results are given in section 3.1.4.

2.2.5. N-methylation of ciprofloxacin, 1 -cyclopropyl-6-fluoro-7-(4-N-methyl-piperazin -1yl)-4-oxo-1, 4-dihydro-quinoline-3-carboxylic acid, 6:

Ciprofloxacin $(1.5 \mathrm{~g}, 4.52 \mathrm{mmol})$ was dissolved in $5 \%$ aqueous $\mathrm{NaOH}$ solution and it was added in dimethyl sulfate $(1.0 \mathrm{~mL})$ with vigorous stirring. The reaction mixture was warmed at $60{ }^{\circ} \mathrm{C}$ with stirring for $90 \mathrm{~min}$ and $\mathrm{pH}$ was adjusted to 4.50 . A crystalline product deposited. It was filtered off, washed with $60 \%$ aqueous ethanol and dried under vacuum in a desiccator. All results are shown in section 3.1.5.

\subsection{Antimicrobial activity (in-vitro)}

\subsubsection{Antibacterial studies}

The antimicrobial activity of the derivatives was determined by the disc diffusion method [26-28] against Gram-positive, Gram-negative bacteria and antifungal strains. The organisms were accumulated as pure cultures. The experiments were carried out in triplicate using ciprofloxacin as standard and the results have been shown as mean $\pm \mathrm{SD}$. For the antibacterial study, $100 \mu \mathrm{g} / \mathrm{mL}$ stock solution of ciprofloxacin and its derivatives were prepared in hot methanol. Commercially available filter paper discs were drenched in the prepared drug and analogues solution, dried and applied on the surface of solid culture media (Nutrient agar), which had been streaked with standardized bacterial inoculums and incubated at $37{ }^{\circ} \mathrm{C}$ for $24 \mathrm{~h}$. This method is based on the determination of an inhibited zone comparative to the bacterial susceptibility to the antibacterial present in the disc. The compounds were screened for their antibacterial activity and compared with the parent against three different Gram-positive strains, i.e., Staphylococcus aureus, Streptococci, Bacillus spp, and five Gram-negative strains, i.e., E. coli, Klebsiella pneumoniae, V. cholerae, Salmonella spp, and Shigella dysenteriae. The results are presented in Tables 1 and 2. 


\subsubsection{Antifungal studies}

For the antifungal assay, $100 \mu \mathrm{g} / \mathrm{mL}$ stock solution of ciprofloxacin and its derivatives were prepared in hot methanol. The stock solutions were diluted to three different concentrations, i.e. 20,40 and $60 \mu \mathrm{g} / \mathrm{mL}$. Commercially available filter paper discs were impregnated with the prepared solutions of the drugs and its derivatives, dried and applied on the surface of the agar plate over which a culture of microorganism was already streaked. After $48 \mathrm{~h}$ of incubation at $37{ }^{\circ} \mathrm{C}$, the clear zone of inhibition around the disc was determined; this is proportional to the fungal susceptibility for the fungal agent present in the disc. The results have been shown as mean \pm SD. Ciprofloxacin and its derivatives were screened for their antifungal activity against the fungi; Candida albicans, Fusarium solani and Aspergillus fumigatus and compared with the parent as well as an antifungal drug miconazole nitrate. The results of antifungal activity are given in Table 3 .

Table 1. Zone of inhibition ( $\mathrm{mm})$ of the compounds $(100 \mu \mathrm{g} / \mathrm{mL})$ against bacteria.

\begin{tabular}{cccc}
\hline \multirow{2}{*}{$\begin{array}{c}\text { Compound } \\
\text { no. }\end{array}$} & \multicolumn{3}{c}{ Gram-positive bacteria } \\
\cline { 2 - 4 } & Staphylococcus aureus & Streptococci & Bacillus spp \\
\hline $\mathbf{1}$ & $18.02 \pm 0.02$ & $14.10 \pm 0.01$ & $16.30 \pm 0.02$ \\
$\mathbf{2}$ & $23.12 \pm 0.01$ & $17.30 \pm 0.03$ & $16.84 \pm 0.02$ \\
$\mathbf{3}$ & $24.80 \pm 0.04$ & $15.94 \pm 0.02$ & $18.02 \pm 0.01$ \\
$\mathbf{4}$ & $23.12 \pm 0.01$ & $14.06 \pm 0.02$ & $15.62 \pm 0.02$ \\
$\mathbf{5}$ & $8.52 \pm 0.02$ & $9.02 \pm 0.02$ & $8.01 \pm 0.12$ \\
$\mathbf{6}$ & $18.10 \pm 0.02$ & $13.94 \pm 0.11$ & $16.32 \pm 0.08$ \\
\hline
\end{tabular}

Table 2. Zone of inhibition (mm) of the compounds $(100 \mu \mathrm{g} / \mathrm{mL})$ against bacteria.

\begin{tabular}{llllll}
\hline \multirow{2}{*}{ Compound } & \multicolumn{5}{l}{ Gram-negative bacteria } \\
\cline { 2 - 6 } no. & $\mathrm{a}$ & $\mathrm{b}$ & $\mathrm{c}$ & $\mathrm{d}$ & $\mathrm{e}$ \\
\hline $\mathbf{1}$ & $12.22 \pm 0.04$ & $24.24 \pm 0.08$ & $21.68 \pm 0.01$ & $26.20 \pm 0.01$ & $26.12 \pm 0.02$ \\
$\mathbf{2}$ & $14.20 \pm 0.05$ & $15.44 \pm 0.04$ & $24.20 \pm 0.04$ & $26.48 \pm 0.04$ & $15.62 \pm 0.05$ \\
$\mathbf{3}$ & $18.24 \pm 0.08$ & $26.28 \pm 0.04$ & $27.82 \pm 0.03$ & $27.38 \pm 0.04$ & $28.36 \pm 0.06$ \\
$\mathbf{4}$ & - & $13.32 \pm 0.06$ & $14.20 \pm 0.04$ & $19.82 \pm 0.03$ & $10.12 \pm 0.06$ \\
$\mathbf{5}$ & - & $12.52 \pm 0.04$ & $12.42 \pm 0.12$ & $20.24 \pm 0.02$ & $10.18 \pm 0.02$ \\
$\mathbf{6}$ & $8.82 \pm 0.12$ & $22.38 \pm 0.05$ & $21.60 \pm 0.08$ & $21.32 \pm 0.01$ & $11.66 \pm 0.02$ \\
\hline $\mathrm{a}=$ E. coli, $\mathrm{b}=$ Klebsiella & pneumoniae, $\mathrm{c}=$ V. cholerae, $\mathrm{d}=$ Salmonella spp and \\
$\mathrm{e}=$ Shigella dysenteriae &
\end{tabular}

\subsection{Cytotoxicity bioassay (in-vitro)}

The cytotoxic activity of the synthesized compounds was measured by brine shrimp lethality assay [29,30]. For determining cytotoxic activity $4.0 \mathrm{mg}$ of each compound was dissolved in $10 \mathrm{~mL}$ of DMSO to get the first concentration $400 \mu \mathrm{g} / \mathrm{mL}$ and diluted to 200 , $100,50,25,12.5,6.25,3.125,1.563,0.781$ and $0.0390 \mu \mathrm{g} / \mathrm{mL}$ using DMSO with the help of micropipette. An equal amount of the vincristine sulfate was dissolved in DMSO to get a preliminary concentration of $400 \mu \mathrm{g} / \mathrm{mL}$ from which solution with decreasing concentration was made by serial dilutions using DMSO to get 200, 100, 50, 25, 12.5, 
$6.25,3.125,1.563,0.781$ and $0.039 \mu \mathrm{g} / \mathrm{mL}$. Brine shrimps (Artemia salina) were hatched using brine shrimp eggs in a conically shaped vessel $(1 \mathrm{~L})$, filled with sterile artificial seawater (prepared using sea salt $38 \mathrm{~g} / \mathrm{L}$ and adjusted to $\mathrm{pH} 8.5$ using $1 \mathrm{~N} \mathrm{NaOH}$ ) under constant aeration for $48 \mathrm{~h}$. After hatching, active nauplii free from eggshells were collected from a brighter portion of the hatching chamber and used for the assay. Ten nauplii were drawn through a glass capillary and placed in each vial containing $4.5 \mathrm{~mL}$ of brine solution. In each experiment, $0.5 \mathrm{~mL}$ of the sample was added to $4.5 \mathrm{~mL}$ of brine solution and maintained at $25{ }^{\circ} \mathrm{C}$ for $24 \mathrm{~h}$ under the light and surviving larvae were counted. The median lethal concentration $\mathrm{LC}_{50}$ of the test samples was obtained by a plot of percentage of the shrimps killed against the logarithm of the sample concentration. The best-fit line was obtained from the graph. The readings were taken in triplicate. The anticancer drug vincristine sulfate was used as the positive control and DMSO as the negative control for the experiment. $\mathrm{LC}_{50}$ results of the compounds are shown in Table 4.

Table 3. Zone of inhibition (mm) of the compounds against various fungi.

\begin{tabular}{|c|c|c|c|c|c|c|c|c|c|}
\hline \multirow[t]{2}{*}{$\begin{array}{l}\text { Compound } \\
\text { no. }\end{array}$} & \multicolumn{3}{|c|}{$\begin{array}{l}\text { Candida albicans } \\
(\mu \mathrm{g} / \mathrm{mL})\end{array}$} & \multicolumn{3}{|c|}{$\begin{array}{l}\text { Fusarium solani } \\
(\mu \mathrm{g} / \mathrm{mL})\end{array}$} & \multicolumn{3}{|c|}{$\begin{array}{l}\text { Aspergillus fumigatus } \\
(\mu \mathrm{g} / \mathrm{mL})\end{array}$} \\
\hline & 20 & 40 & 60 & 20 & 40 & 60 & 20 & 40 & 60 \\
\hline 1 & - & $\begin{array}{l}8.06 \\
\pm 0.01\end{array}$ & $\begin{array}{l}9.92 \\
\pm 0.02\end{array}$ & - & - & - & - & - & - \\
\hline 2 & $\begin{array}{l}12.30 \\
\pm 0.02\end{array}$ & $\begin{array}{l}12.86 \\
\pm 0.02\end{array}$ & $\begin{array}{l}14.20 \\
\pm 0.04\end{array}$ & - & $\begin{array}{l}8.04 \\
\pm 0.01\end{array}$ & $\begin{array}{l}8.42 \\
\pm 0.02\end{array}$ & - & $\begin{array}{l}8.02 \\
\pm 0.04\end{array}$ & $\begin{array}{l}10.10 \\
\pm 0.01\end{array}$ \\
\hline 3 & $\begin{array}{l}12.02 \\
\pm 0.01\end{array}$ & $\begin{array}{l}13.62 \\
\pm 0.01\end{array}$ & $\begin{array}{l}15.04 \\
\pm 0.02\end{array}$ & - & $\begin{array}{l}8.06 \\
\pm 0.08\end{array}$ & $\begin{array}{l}8.26 \\
\pm 0.04\end{array}$ & - & $\begin{array}{l}8.04 \\
\pm 0.01\end{array}$ & $\begin{array}{l}8.96 \\
\pm 0.02\end{array}$ \\
\hline 4 & $\begin{array}{l}10.34 \\
\pm 0.01\end{array}$ & $\begin{array}{l}11.08 \\
\pm 0.02\end{array}$ & $\begin{array}{l}12.64 \\
\pm 0.04\end{array}$ & - & $\begin{array}{l}8.42 \\
\pm 0.02\end{array}$ & $\begin{array}{l}9.12 \\
\pm 0.02\end{array}$ & - & $\begin{array}{l}9.04 \\
\pm 0.04\end{array}$ & $\begin{array}{l}10.46 \\
\pm 0.04\end{array}$ \\
\hline 5 & $\begin{array}{l}9.08 \\
\pm 0.01\end{array}$ & $\begin{array}{l}10.16 \\
\pm 0.01\end{array}$ & $\begin{array}{l}12.04 \\
\pm 0.02\end{array}$ & - & $\begin{array}{l}9.24 \\
\pm 0.02\end{array}$ & $\begin{array}{l}10.38 \\
\pm 0.01\end{array}$ & - & - & - \\
\hline 6 & - & - & $\begin{array}{l}9.40 \\
\pm 0.01\end{array}$ & - & $\begin{array}{l}9.22 \\
\pm 0.01\end{array}$ & $\begin{array}{l}10.72 \\
\pm 0.02\end{array}$ & - & $\begin{array}{l}8.06 \\
\pm 0.04\end{array}$ & $\begin{array}{l}10.00 \\
\pm 0.12\end{array}$ \\
\hline MN & $\begin{array}{l}23.46 \\
\pm 0.14\end{array}$ & $\begin{array}{l}28.08 \\
\pm 0.01\end{array}$ & $\begin{array}{l}34.00 \\
\pm 0.02\end{array}$ & $\begin{array}{l}22.04 \\
\pm 0.02\end{array}$ & $\begin{array}{l}26.68 \\
\pm 0.01\end{array}$ & $\begin{array}{l}29.86 \\
\pm 0.01\end{array}$ & $\begin{array}{l}20.24 \\
\pm 0.02 \\
\end{array}$ & $\begin{array}{l}26.14 \\
\pm 0.01\end{array}$ & $\begin{array}{l}28.36 \\
\pm 0.04\end{array}$ \\
\hline
\end{tabular}

MN = Miconazole nitrate

Table $4 . \mathrm{LC}_{50}$ of the compounds against brine shrimps.

\begin{tabular}{lccccccc}
\hline Compound no. & $\mathbf{1}$ & $\mathbf{2}$ & $\mathbf{3}$ & $\mathbf{4}$ & $\mathbf{5}$ & $\mathbf{6}$ & $\mathrm{VS}$ \\
\hline $\mathrm{LC}_{50}(\mu \mathrm{g} / \mathrm{mL})$ & 36.42 & 36.02 & 20.72 & 18.02 & 08.46 & 36.12 & 0.78 \\
\hline $\mathrm{VS}=$ Vincristine sulfate & & & & & &
\end{tabular}

\section{Results and Discussion}

\subsection{Chemistry}

Ciprofloxacin has, besides other groups, the secondary amino group which can be readily converted to various derived products. To study the antibacterial, antifungal, and 
cytotoxicity, the five derived products of ciprofloxacin based on secondary amino group, 2-6 were synthesized and characterized by m.p., TLC, HPLC, FT-IR, ${ }^{1} \mathrm{H}-\mathrm{NMR},{ }^{13} \mathrm{C}-\mathrm{NMR}$, ESI-MS, and elemental analysis.

Derivative, 2: Ciprofloxacin was converted to its enamine derivative, 2 with N-methyl-2pyrrolidone with $69 \%$ yield. The distinct melting point and TLC $R_{\mathrm{f}}$ value give introductory information about the formation of derivative, 2. It was $98.64 \%$ pure as determined by HPLC. The infrared spectrum showed a new stretching absorption band at $2856 \mathrm{~cm}^{-1}$ for $\mathrm{C}-\mathrm{H}$ of the $\mathrm{CH}_{3}$ group and absence of $\mathrm{N}-\mathrm{H}$ stretching band at $3350 \mathrm{~cm}^{-1}$ of ciprofloxacin that confirmed with the proposed structure, 4. Further, the enamine derivative is confirmed by the ${ }^{1} \mathrm{H}$ and ${ }^{13} \mathrm{C}$-NMR spectra. The ${ }^{1} \mathrm{H}$-NMR spectrum showed four new bands at $\delta 3.33\left(\mathrm{~s}, 1 \mathrm{H}, \mathrm{H}-66^{\prime}\right), 2.93\left(\mathrm{~s}, 3 \mathrm{H}, \mathrm{N}-\mathrm{CH}_{3}\right), 2.69\left(\mathrm{~s}, 1 \mathrm{H}, \mathrm{H}-4^{\prime}\right)$ and 2.23 (s, $\left.1 \mathrm{H}, \mathrm{H}-5^{\prime}\right)$ that confirmed the introduction of an $\mathrm{N}$-methyl pyrrole moiety in the derivative. ${ }^{13} \mathrm{C}$ spectrum is also consistent with this finding, enamine carbon $\mathrm{C}-2$ ' appeared at $\delta$ $163.63, \mathrm{C}-6$ ' at $\delta 73.1, \mathrm{C}-4$ ' and $\mathrm{N}$-methyl carbons appeared at $\delta 50-52$. Finally, the ESIMS showed the $\left(\mathrm{M}+\mathrm{H}^{+}\right)$peak at 416.1848 appropriate for $\mathrm{C}_{22} \mathrm{H}_{25} \mathrm{FN}_{4} \mathrm{O}_{3}$ and the elemental analysis results $(\% \mathrm{C}, \mathrm{H}$, and $\mathrm{N})$ gave the satisfactory results which also established molecular formula and structure of the derivative (section 3.1.1).

Derivative, 3: Ciprofloxacin was converted to its enamine derivative, $\mathbf{3}$ using camphor. It was obtained in $68.60 \%$ yield. The melting point and $\mathrm{R}_{\mathrm{f}}$ value primarily confirmed the derivative of ciprofloxacin. It was $98.80 \%$ pure as determined by HPLC. The IR spectrum displayed most of the bands like ciprofloxacin excluding one at $3350 \mathrm{~cm}^{-1}(\mathrm{~N}-\mathrm{H}$ str.) and showed a new band at $2856 \mathrm{~cm}^{-1}\left(\mathrm{C}-\mathrm{H}\right.$ str., $\left.\mathrm{CH}_{3}\right)$ which indicated the methyl group present in the molecule and confirmed $2^{\circ}$ amino group of ciprofloxacin had enamine formation with camphor. That ciprofloxacin has reacted with camphor is revealed by the ${ }^{1} \mathrm{H}-\mathrm{NMR}$. The new peak in the aliphatic region was a very broad multiplet $\delta 1.19-1.54(\mathrm{H}-11,12,13,14 \& 14$ ') along with two peaks at $\delta 2.26$ (br s, $1 \mathrm{H}, \mathrm{H}-10)$ and $5.02(\mathrm{~d}, 1 \mathrm{H}, \mathrm{H}-9)$ for allylic and vinylic protons that confirmed the enamine formation in ciprofloxacin. ${ }^{13} \mathrm{C}$ spectrum is also consistent with this finding, enamine carbon $\mathrm{C}-2^{\prime}$ appeared at $\delta 158.62, \mathrm{C}^{\prime} 3^{\prime}$ at $\delta 104.15, \mathrm{C}-4^{\prime} \mathrm{C}-\mathrm{7}^{\prime} \& \mathrm{C}-8^{\prime}$ at $\delta 50-56, \delta 36-25$ for C-5', C-6', and $\delta 8-14$ (C-9' C-10' and C-11') that over again confirmed a camphor moiety in the derivative. The ESI-MS showed the $\left(\mathrm{M}+\mathrm{Na}^{+}\right.$) peak at 488.5528 for $\mathrm{C}_{27} \mathrm{H}_{33} \mathrm{NaFN}_{3} \mathrm{O}_{3}$ which was also in good agreement with elemental analysis results $(\% \mathrm{C}, \mathrm{H}, \mathrm{N})$ that finally confirmed the structure of derivative, 3 (section 3.1.2).

Derivative, 4: Ciprofloxacin was heated with 1-cyanoguanidine to give derivative, $\mathbf{4}$ with $71.80 \%$ yield. The yellow color, melting point, and $R_{\mathrm{f}}$ value give initial information about the formation of the derivative. It was $97.81 \%$ pure as determined by HPLC. The IR spectrum of the derivative exhibited similar bands like ciprofloxacin except for three new strong bands at $3559,3490.33$ and $3402.43 \mathrm{~cm}^{-1}$ which can be attributed to $v \mathrm{~N}-\mathrm{H}$ of the primary and secondary amine of cyanoguanidino moiety that confirmed the formation of 
the derivative. The ${ }^{1} \mathrm{H}-\mathrm{NMR}$ spectrum showed some new peaks, e.g. in the aliphatic region $2 \mathrm{H}$ broad singlet $\delta 5.75$ due to $\mathrm{H}-4^{\prime} 1^{\circ}$ amino group moreover; a broad $2 \mathrm{H}$ singlet appeared at $\delta 9.46$ due to $\mathrm{H}-2^{\prime}, \mathrm{H}-4^{\prime}$ for $(=\mathrm{NH})$ that confirmed for a second time the formation of the derivative. ${ }^{13} \mathrm{C}-\mathrm{NMR}$ decoupled spectrum displayed all peaks of ciprofloxacin besides two extra signals at $\delta 162.54$ and 164.53 due to (C-4') and (C-2') respectively that also evident the derivative. As a final point, the derivative showed $\mathrm{m} / \mathrm{z}$ peak at 416.1978 for $(\mathrm{M}+\mathrm{H}), \mathrm{C}_{19} \mathrm{H}_{23} \mathrm{FN}_{7} \mathrm{O}_{3}$ and the elemental analysis results $(\% \mathrm{C}, \mathrm{H}, \mathrm{N})$ agreed with the molecular formula (section 3.1.3).

Derivative, 5: Ciprofloxacin was heated with 1-cyanonaphthalen to give derivative, 5 with $73 \%$ yield. The yellow color, melting point, and $R_{\mathrm{f}}$ value give early information regarding the formation of the derivative. HPLC system had purity $98.64 \%$. The IR spectrum of 5 showed one new strong band at $3402 \mathrm{~cm}^{-1}$ which corresponds to $v=\mathrm{N}-\mathrm{H}$ of the secondary amine of cyanonaphthaleno-moiety and absence of the $v \mathrm{~N}-\mathrm{H}$ band at $3350 \mathrm{~cm}^{-1}$ of ciprofloxacin; other bands are consistent with the proposed structure, 5. The ${ }^{1} \mathrm{H}-\mathrm{NMR}$ spectrum of 5 showed some new peaks, $\delta 9.49$ ( s, 1H, H-2'); $\delta 8.50$ ( s, 2H, H-6' H-7'); $\delta$ $7.72\left(\mathrm{~d}, 1 \mathrm{H}, \mathrm{H}-10^{\prime}\right) ; \delta$ 7.5- 7.26 ( $\mathrm{m}, 5 \mathrm{H}, \mathrm{H}-4^{\prime} \mathrm{H}-5^{\prime}$ H-8' H-9' and H-8) that confirmed the formation the derivative. ${ }^{13} \mathrm{C}-\mathrm{NMR}$ decoupled spectrum of $\mathbf{5}$ displayed all peaks of ciprofloxacin; besides, some extra signals at $\delta 164.53$ for (C-2'); and $\delta 122-133$ (10 C, naphthalene) confirmed the derivative. Finally, the derivative showed $\mathrm{m} / \mathrm{z}$ peak at 485.1845 for $(\mathrm{M}+\mathrm{H}), \mathrm{C}_{28} \mathrm{H}_{25} \mathrm{FN}_{4} \mathrm{O}_{3}$ and the elemental analysis results $(\% \mathrm{C}, \mathrm{H}, \mathrm{N})$ were in agreement with the molecular formula (section 3.1.4).

Derivative, 6: Ciprofloxacin was methylated with dimethylsulfate in the presence of sodium hydroxide with $73.72 \%$ yield. The melting point and $R_{\mathrm{f}}$ value give opening information about the formation of the derivative, 6. HPLC system, the purity was 98.80 $\%$. The IR spectrum revealed similar bands like ciprofloxacin except for a new one at $2856 \mathrm{~cm}^{-1}$ for $\mathrm{vC}-\mathrm{H}\left(\mathrm{N}-\mathrm{CH}_{3}\right)$ which confirmed the formation of the derivative. The conversion of ciprofloxacin to its $\mathrm{N}$-methyl derivative was confirmed by the ${ }^{1} \mathrm{H}$ and ${ }^{13} \mathrm{C}$ NMR spectra. The methyl protons of the $\mathrm{N}^{-\mathrm{CH}_{3}}$ group appeared as a $3 \mathrm{H}$ singlet at $\delta 2.57$ which are not present in ciprofloxacin. The ${ }^{13} \mathrm{C}$ spectrum $\mathrm{N}_{-} \mathrm{CH}_{3}$ appeared at $\delta 40.69$. This derivative showed $\mathrm{m} / \mathrm{z}$ peak at 346.3868 for $\mathrm{C}_{18} \mathrm{H}_{21} \mathrm{FN}_{3} \mathrm{O}_{4}$ as $(\mathrm{M}+\mathrm{H})$. There is a good agreement with the elemental analysis report $(\% \mathrm{C}, \mathrm{H}$, and $\mathrm{N})$ with the formula $\mathrm{C}_{18} \mathrm{H}_{20} \mathrm{FN}_{3} \mathrm{O}_{4}$ (section 3.1.5).

\subsubsection{Finding of derivative, 2:}

The product was obtained as white crystals; yield 1.28 g, $69 \%$; m.p. 222-223 ${ }^{\circ} \mathrm{C}$; TLC $R_{\mathrm{f}}$ 0.64; HPLC system had purity $98.64 \%$; IR $\left(\mathrm{KBr}, v \mathrm{~cm}^{-1}\right)$ : 3420 (O-H str.); 3055 (C-H str., aromatic); 2902 (C-H str., $\left.\mathrm{CH}_{2}\right)$; 2856 (C-H str., $\left.\mathrm{CH}_{3}\right) ; 1717$ (C=O, conjugated $\left.\mathrm{COOH}\right)$; 1631 (C=O str., conjugated quinolone); 1290 (C-N str.); 1238 (C-O str.); 1227 (C-F str.); ${ }^{1} \mathrm{H}-\mathrm{NMR}$ (DMSO-d 6 , $400 \mathrm{MHz}$ ): $\delta 10.92$ (s, 1H, H-14, COOH); 8.67 (s, 1H, H-2, aryl H); 
$7.92\left(\mathrm{~d}, 1 \mathrm{H}, J_{\mathrm{HF}}=13.2 \mathrm{~Hz}, \mathrm{H}-5\right.$, aryl H); $7.58\left(\mathrm{~d}, 1 \mathrm{H}, J_{\mathrm{HF}}=4.2 \mathrm{~Hz}, \mathrm{H}-8\right.$, aryl H); $3.84(\mathrm{~m}$, 1H, H-11, cyclopropane); 3.43 (s, 4H, H-16, H-20 piperazinyl H); 3.33 (s, 1H, H-6'); 3.17 (s, 4H, H-17, H-19, piperazinyl H); 2.93 (s, 3H, H-3', N-CH - $_{3}$; 2.69 (s, 1H, H-4'); 2.23 (s, 1H, H-5'); 1.31(m, 2H, H-12, cyclopropane); 1.18 (m, 2H, H-13, cyclopropane); ${ }^{13} \mathrm{C}-\mathrm{NMR}$ (DMSO-d $6,100 \mathrm{MHz}): \delta 182.11$ (C-4, C=0 quinolone); 161.63 (C-2'); 166.64 (C-14, $\mathrm{COOH}$ ); 154.32 (C-6); 148.82 (C-2); 146.10 (C-7); 139.9 (C-10); 111.73 (C-9); 107.53 (C-5); 107.3 (C-3); 99.15 (C-8); 73.1 (C-6'); 50-52 (2C, C-4' and N-methyl); 36-39 (4C, C piperazin); 27.6 (C-5'); 8-14 (3C, C cyclopropane); Anal. calcd. for $\mathrm{C}_{22} \mathrm{H}_{25} \mathrm{FN}_{4} \mathrm{O}_{3}: \mathrm{C}$, 64.06; H, 6.11; N, $13.58 \%$; found: C, 63.56; H, 6.21; N, $12.66 \%$; ESI-MS m/z calcd. for $\mathrm{C}_{22} \mathrm{H}_{25} \mathrm{FN}_{4} \mathrm{O}_{3}+\left(\mathrm{H}^{+}\right): 412.1946$; found: 416.1848 .

\subsubsection{Finding of derivative, 3 :}

The product was obtained as white crystals; yield 1.44 g, $68.60 \%$; m.p. $260-261{ }^{\circ} \mathrm{C}$; TLC $R_{\mathrm{f}} 0.65$; HPLC system purity $98.80 \%$; IR( $\left.\mathrm{cm}^{-1}\right)$ : 3454 (O-H str.); 3101, 3057(C-H str., aromatic, C-H str.,); 2954(C-H str., $\left.\mathrm{CH}_{2}\right) ; 2859$ (C-H str., $\left.\mathrm{CH}_{3}\right) ; 1718(\mathrm{C}=\mathrm{O}$ str., $\mathrm{COOH})$; 1632(C=O str., qunilone); 1301(C-N str.); 1258(C-O str.); 1231(C-F str.); ${ }^{1} \mathrm{H}-\mathrm{NMR}$ (DMSO- $\left.d_{6}, 400 \mathrm{MHz}\right): \delta 10.80$ (s, $\left.1 \mathrm{H}, \mathrm{H}-14, \mathrm{COOH}\right) ; 8.64$ (s, 1H, H-2); 7.85(d, 1H, H-5); 7.52(d, 1H, H-8); 5.02 (d, 1H, H-3'); 3.82 (m, 1H, H-11); 3.22 (t, 4H, H-16, H-20); 2.88 (t, 4H, H-17, H-19); 1.19 -1.54 (br m, 14H, H-4', H-12', H-5', H-6', H-9' H-10' \& H-11'); 1.14 (m, 2H, H-12, H-13); 1.09 (m, 2H, H-12, H-13); ${ }^{13}$ C-NMR (DMSO-d, 100 MHz): $\delta$ 182.81 (C-4, C=0 quinolone); 166.04 (C-14, $\mathrm{COOH}) ; 158.62$ (C-2'); 152.82 (C-6); 148.22 (C-2); 146.55 (C-7); 137.92 (C-10); 113.26 (C-9); 113.53 (C-5); 107.34 (C-3); 104.15 (C3'); 100.15 (C-8); 50-56 (7C, C-16, C-17, C-19, C-20, C-4' C-7' and C-8'); 36-25 (3C, C11 piperazin, C-5', C-6'); 8-14 (5C, C-12, C-13 cyclopropane, C-9', C-10' and C-11'); Anal. calcd. for $\mathrm{C}_{27} \mathrm{H}_{32} \mathrm{FN}_{3} \mathrm{O}_{3}: \mathrm{C}, 69.66 ; \mathrm{H}, 6.93 ; \mathrm{N}, 9.03 \%$; found: C, 69.54; H, 6.80; N, $9.22 \%$; ESI-MS m/z calcd. for $\mathrm{C}_{27} \mathrm{H}_{32} \mathrm{FN}_{3} \mathrm{O}_{3}+(\mathrm{Na}+)$ : 488.2325 ; found: 488.3528 .

\subsubsection{Finding of derivative, 4 :}

The product was obtained as yellow crystals; yield 0.90 g, $71.80 \%$; m.p. $235-236{ }^{\circ} \mathrm{C}$; TLC $R_{\mathrm{f}} 0.53$; and HPLC system purity $97.81 \%$; IR $\left(\mathrm{cm}^{-1}\right): 3559,3490$ and 3402 (N-H str., $1^{0}$ and $2^{0}$ amine); 3093 (C-H str., aromatic); $2917\left(\mathrm{C}-\mathrm{H}\right.$ str. $\left.\mathrm{CH}_{2}\right) ; 1720(\mathrm{C}=\mathrm{O}$ str., $\mathrm{COOH}$, 1627 (C=O str., conjugated quinolone); 1285 (C-N str.); 1241(C-O str.); 1228 (C-F str.); ${ }^{1} \mathrm{H}-\mathrm{NMR}$ (DMSO- $d_{6}, 400 \mathrm{MHz}$ ): $\delta 10.78(\mathrm{~s}, 1 \mathrm{H}, \mathrm{H}-14, \mathrm{COOH}) ; 9.46$ (br s, 2H, H-2', H4'); $8.65\left(\mathrm{~s}, 1 \mathrm{H}, \mathrm{H}-2\right.$, aryl H); $7.92\left(\mathrm{~d}, 1 \mathrm{H}, J_{\mathrm{HF}}=13.2 \mathrm{~Hz}, \mathrm{H}-5\right.$, aryl H); $7.58\left(\mathrm{~d}, 1 \mathrm{H}, J_{\mathrm{HF}}=\right.$ $4.2 \mathrm{~Hz}, \mathrm{H}-8$, aryl H); 5.75 (br s, 2H, H-4' $1^{\circ}$ amine); 3.84 (m, 1H, H-11, cyclopropane); 3.43 (s, 4H, H-16, H-20 piperazinyl H); 3.17 (s, 4H, H-17, H-19, piperazinyl H); 1.31(m, 2H, H-12, cyclopropane); 1.10 (m, 2H, H-13, cyclopropane); ${ }^{13}$ C-NMR (DMSO-d 6100 $\mathrm{MHz}$ ): $\delta 188.11$ (C-4, C=0 quinolone); 167.10 (C-14, COOH); 164.53 (C-4'); 162.54 (C2'); 154.32 (C-6); 148.82 (C-2); 146.10 (C-7); 139.9 (C-10); 111.73 (C-9); 107.53 (C-5); 107.3 (C-3); 99.15 (C-8); 36-39 (4C, C piperazin); 8-14 (3C, C cyclopropane); Anal. 
calcd. for $\mathrm{C}_{19} \mathrm{H}_{22} \mathrm{FN}_{7} \mathrm{O}_{3}: \mathrm{C}, 54.93 ; \mathrm{H}, 5.34 ; \mathrm{N}, 23.60 \%$; found: $\mathrm{C}, 54.03 ; \mathrm{H}, 5.84 ; \mathrm{N}, 23.31$ $\%$; ESI-MS m/z calcd. for $\mathrm{C}_{19} \mathrm{H}_{22} \mathrm{FN}_{7} \mathrm{O}_{3}+\left(\mathrm{H}^{+}\right): 416.1846$; found: 416.1978 .

\subsubsection{Finding of derivative, 5:}

The product was obtained as yellow crystals; yield 1.06 g, $73 \%$; m.p. $285-286{ }^{\circ}$ C; TLC $R_{\mathrm{f}}$ 0.57; HPLC system purity $98.84 \%$; IR $\left(\mathrm{cm}^{-1}\right)$ : 3402 (=N-H str.); 3093 (C-H str., aromatic); 2917 (C-H str. $\mathrm{CH}_{2}$ ); 1628 (C=O str., conjugated quinolone); 1287 (C-N str.); 1244 (C-O str.); 1233 (C-F str.); ${ }^{1} \mathrm{H}-\mathrm{NMR}$ (DMSO-d 6 , $400 \mathrm{MHz}$ ): $\delta 10.92$ (s, 1H, H-14, $\mathrm{COOH}$ ); 9.49 ( s, 1H, H-2'); 8.50 ( s, 2H, H-6' H-7'); 8.68 (s, 1H, H-2, aryl H); 7.98 (d, $1 \mathrm{H}, J_{\mathrm{HF}}=13.2 \mathrm{~Hz}, \mathrm{H}-5$, aryl H); 7.72 (d, 1H, H-10'); 7.5-7.26 ( m, 5H, H-4' H-5' H-8' H-9' and $\mathrm{H}-8$ ); 3.84 (m, 1H, H-11, cyclopropane); 3.43 (s, 4H, H-16, H-20 piperazinyl H); 3.17 (s, 4H, H-17, H-19, piperazinyl H); 1.31 (m, 2H, H-12, cyclopropane); 1.10 (m, 2H, H-13, cyclopropane); ${ }^{13} \mathrm{C}-\mathrm{NMR}$ (DMSO-d $6,100 \mathrm{MHz}$ ): $\delta 186.11$ (C-4, C=0 quinolone); 167.10 (C-14, COOH); 164.53 (C-2'); 154.32 (C-6); 148.82 (C-2); 146.10 (C-7); 139.9 (C10);122-133 (10C, naphthalene ); 111.73 (C-9); 107.53 (C-5); 107.3 (C-3); 99.15 (C-8); 36-39 (4C, C piperazin); 8-14 (3C, C cyclopropane); Anal. calcd. for $\mathrm{C}_{28} \mathrm{H}_{25} \mathrm{FN}_{4} \mathrm{O}_{3}: \mathrm{C}$, 69.41; H, 5.20; N, $11.56 \%$ : found: C, 69.40; H, 5.80; N, $11.22 \%$; ESI-MS m/z calcd. for $\mathrm{C}_{28} \mathrm{H}_{25} \mathrm{FN}_{4} \mathrm{O}_{3}+(\mathrm{H}+)$ : 485.1845; found: 485.1908 .

\subsubsection{Finding of derivative, 6 :}

The derivative, 6 was obtained as white crystals; yield 1.15 g, $73.72 \%$; m.p. $288{ }^{\circ}$ C; TLC $R_{\mathrm{f}} 0.64$; HPLC purity $98.15 \%$; IR $\left(\mathrm{cm}^{-1}\right)$ : 3412 (O-H str., H-bonded); 3055(C-H str., aromatic); 2926 (C-H str., aliphatic); $2856\left(\mathrm{C}-\mathrm{H}\right.$ str., $\left.\mathrm{CH}_{3}\right) ; 1720(\mathrm{C}=\mathrm{O}, \mathrm{COOH}) ; 1629$ (C=O str., conjugated quinolinone ); 1429 (C-N str.); 1367 (C-O str); 1306 (C-F str.); ${ }^{1} \mathrm{H}-$ NMR (DMSO- $\left.d_{6}, 400 \mathrm{MHz}\right): \delta 10.96(\mathrm{~s}, 1 \mathrm{H}, \mathrm{H}-14, \mathrm{COOH}) ; 8.64$ (s, 1H, H-2); 7.86 (d, 1H, H-5); 7.52 (d, 1H, H-8); 3.82 (s, 1H, H-11); 3.32 (s, 4H, H-16, H-20 piperazinyl H); 2.59 (s, 4H, H-17, H-19, piperazinyl H); 2.57 (s, 3H, H-2', N- methyl); 1.29 (m, 2H, H-12, cyclopropane); 1.17 (m, 2H, H-13, cyclopropane); ${ }^{13} \mathrm{C}-\mathrm{NMR}$ (DMSO- $d_{6,100 \mathrm{MHz} \text { ): } \delta}$ 187.11 (C-4, quinolinone $\mathrm{C}=\mathrm{O}) ; 167.64$ (C-9, COOH); 154.32 (C-2); 148.82 (C-6); 146.10 (C-10); 139.90 (C-7); 131.04 (C-5); 111.73 (C-9); 107.53 (C-3); 96.34 (C-8); 57.84 (2C, C-17, C-19); 54.56 (2C, C-16, C-20); 40.69 (C-2'); 36.58 (C-11); 8.41(C-12, C-13); Anal. calcd. for $\mathrm{C}_{18} \mathrm{H}_{20} \mathrm{FN}_{3} \mathrm{O}_{3}$ : C, 62.60; H, 5.84; N, $12.17 \%$; found, C, 62.74; H, 6.04; N, $12.24 \%$; ESI-MS m/z calcd. for $\mathrm{C}_{18} \mathrm{H}_{20} \mathrm{FN}_{3} \mathrm{O}_{3}+\left(\mathrm{H}^{+}\right)$: 346.1556; found: 346.1668.

\subsection{Antibacterial activity}

Zones of inhibition for Gram-positive bacteria (Table 1) indicate that the derivatives, 2-6 showed various degrees of activities compared to ciprofloxacin against the Gram-positive bacterial strains. The derivatives $2(23.12 \pm 0.01 \mathrm{~mm}), \mathbf{3}(24.80 \pm 0.04 \mathrm{~mm})$, and 4 $(23.12 \pm 0.01 \mathrm{~mm})$ showed significantly enhanced activity compared to ciprofloxacin $(18.02 \pm 0.02 \mathrm{~mm})$ against Staphylococcus aureus whereas derivative $6(18.10 \pm 0.02 \mathrm{~mm})$ 
exhibited similar activity but $5(14.52 \pm 0.02 \mathrm{~mm})$ and $\mathbf{6}(13.10 \pm 0.05 \mathrm{~mm})$ exhibited less activity compared to ciprofloxacin. The derivative, $2(17.30 \pm 0.03 \mathrm{~mm})$ and $\mathbf{3}(15.94 \pm 0.02$ $\mathrm{mm})$ showed significantly enhanced activities compared to ciprofloxacin $(14.10 \pm 0.01$ $\mathrm{mm})$ but compounds $4(14.06 \pm 0.02 \mathrm{~mm}), 5(9.02 \pm 0.02 \mathrm{~mm})$, and $\mathbf{6}(13.94 \pm 0.11 \mathrm{~mm})$ exhibited less activity than parent against Streptococci. The compounds $2(16.84 \pm 0.02$ $\mathrm{mm})$, and $\mathbf{3}(18.02 \pm 0.01 \mathrm{~mm})$ exhibited enhanced activity but derivatives $\mathbf{4 , 5}$ and $\mathbf{6}$ were found to be similar or poor in activity against Bacillus spp compared to ciprofloxacin $(16.30 \pm 0.02 \mathrm{~mm})$.

Zones of inhibition (Table 2) signify that the derivatives exhibited different activities compared to ciprofloxacin against the Gram-negative bacterial strains. The compounds 2 $(14.20 \pm 0.05 \mathrm{~mm})$ and $\mathbf{3}(18.24 \pm 0.08 \mathrm{~mm})$ were found to show enhanced activity but the derivative $\mathbf{6}(8.82 \pm 0.04 \mathrm{~mm})$ exhibited poor activity and rest of derivatives $\mathbf{4}$ and $\mathbf{5}$ were found to possess no activity compared to ciprofloxacin $(12.22 \pm 0.04 \mathrm{~mm})$ against $E$. coli. Among the derivatives, only compound $3(26.28 \pm 0.04 \mathrm{~mm})$ exhibited enhanced activity compared to ciprofloxacin $(24.24 \pm 0.08 \mathrm{~mm})$ but derivatives $2(15.44 \pm 0.04 \mathrm{~mm}), 4$ $(13.32 \pm 0.06 \mathrm{~mm}), 5(12.52 \pm 0.04 \mathrm{~mm})$ and $\mathbf{6}(13.28 \pm 0.04 \mathrm{~mm})$ showed poor activities compared to ciprofloxacin against Klebsiella pneumoniae.

The derivatives $2(24.20 \pm 0.04 \mathrm{~mm})$ and $\mathbf{3}(27.82 \pm 0.03 \mathrm{~mm})$ showed enhanced activities compared to ciprofloxacin $(21.68 \pm 0.01 \mathrm{~mm})$ but compounds $4(14.20 \pm 0.04$ $\mathrm{mm}), 5(12.42 \pm 0.12 \mathrm{~mm})$ and $\mathbf{6}(21.60 \pm 0.08 \mathrm{~mm})$ are found to be similar or less active compared to ciprofloxacin against $V$. cholerae. The derivatives, $2(26.48 \pm 0.04 \mathrm{~mm})$ and $\mathbf{3}$ $(27.38 \pm 0.04 \mathrm{~mm})$ showed enhanced activities compared to ciprofloxacin $(26.20 \pm 0.01 \mathrm{~mm})$ but the compounds $4(19.82 \pm 0.03 \mathrm{~mm}), \mathbf{5}(20.24 \pm 0.02 \mathrm{~mm})$, and $\mathbf{6}(21.32 \pm 0.01 \mathrm{~mm})$ are found to be less active compared to ciprofloxacin against Salmonella spp. Only the compound $3(28.36 \pm 0.06 \mathrm{~mm})$ possessed enhanced activity compared to ciprofloxacin $(26.24 \pm 0.08 \mathrm{~mm})$ but derivatives $\mathbf{2}, \mathbf{4}, \mathbf{5}$, and $\mathbf{6}$ showed less activity compared to ciprofloxacin against Shigella dysenteriae.

\subsection{Antifungal activity}

Zones of inhibition for the fungi (Table 3$)$ indicate that the derivatives, $2(14.20 \pm 0.04$ $\mathrm{mm}), \mathbf{3}(15.04 \pm 0.02 \mathrm{~mm}), 4(12.64 \pm 0.04 \mathrm{~mm}), \mathbf{5}(12.04 \pm 0.02 \mathrm{~mm})$, and $\mathbf{6}(9.40 \pm 0.01$ $\mathrm{mm})$ exhibited effective activities compared to ciprofloxacin $(9.92 \pm 0.02 \mathrm{~mm}$ ) against Candida albicans but less than that of miconazole nitrate $(34.00 \pm 0.02 \mathrm{~mm})$. Ciprofloxacin and its derivatives 2-6 exhibited poor activity against Fusarium solani and Aspergillus fumigatus compared to miconazole nitrate; however, among the derivatives compound, $\mathbf{3}$ is found to be most potent.

\subsection{Cytotoxicity}

Ciprofloxacin and its analogues 2-6 demonstrated a varying degree of cytotoxic activities (Table 4). Most of the derivatives are found to have slightly more cytotoxic activities compared to ciprofloxacin. Among the compounds the lowest $\mathrm{LC}_{50}$ is shown by 
derivatives $3(20.72 \mu \mathrm{g} / \mathrm{mL}), \mathbf{4}(18.20 \mu \mathrm{g} / \mathrm{mL})$ and $\mathbf{5}(8.46 \mu \mathrm{g} / \mathrm{mL})$, confirmed the most potent cytotoxic agent compared to ciprofloxacin $(36.42 \mu \mathrm{g} / \mathrm{mL})$ but less than vincristine sulfate $(0.78 \mu \mathrm{g} / \mathrm{mL})$. However, amongst the derivatives analogue, $\mathbf{5}$ is found to be the most potent.

\section{Conclusion}

In this paper, five analogues of ciprofloxacin have been successfully synthesized. The structure of the analogues was confirmed by different techniques i.e. IR, ${ }^{1} \mathrm{H}-\mathrm{NMR},{ }^{13} \mathrm{C}$ NMR and mass spectrometry together with elemental analysis. The structural analogues of ciprofloxacin, $\mathbf{1}$ showed varying degree of antibacterial activity against the tested bacterial strains. Zones of inhibition of bacterial strains implied that derivative, $\mathbf{2}$ exhibited enhanced activities against Staphylococcus aureus, Streptococci, Bacillus spp, E. coli, V. cholerae, and Salmonella spp compared to ciprofloxacin. Derivative $\mathbf{3}$ exhibited enhanced activity against all of the Gram-positive and Gram-negative tested bacterial strains; Compound, $\mathbf{4}$ showed enhanced activities against Staphylococcus aureus, Streptococci, Bacillus spp; $\mathbf{5}$ showed poor activity against all of the Gram-positive and Gram-negative tested bacterial strains; $\mathbf{6}$ exhibited more or less similar activity against tested bacterial strains compared to the parent. On the other hand, most of the derivatives possessed valuable antifungal properties against Candida albicans but poor activity against Fusarium solani and Aspergillus fumigatus whereas parent, 1 did not demonstrate any activity. Most of the derivatives showed cytotoxic activity where derivatives $\mathbf{4}$ and $\mathbf{5}$ were found to be the most potent cytotoxic agent compared to ciprofloxacin. The comparison of the activities of different analogues of ciprofloxacin indicated that the amidic linkage of an alkyl group at piperazine moiety may be responsible for the change in the biological properties of the parent.

\section{References}

1. G. C. Crumplin and J. T. Smith, Nature 260, 643 (1976). https://doi.org/10.1038/260643a0

2. J. C. Wang, Annu. Rev. Biochem. 54, 665 (1985). https://doi.org/10.1146/annurev.bi.54.070185.003313

3. M. Gellert, K. Mizuuchi, and M. H. O’Dea, Proc. Natl. Acad. Sci. USA 74, 4772 (1977). https://dx.doi.org/10.1073\%2Fpnas.74.11.4772

4. S. H. Choi, Y. E. Kim, and Y. J. Kim, Kor. J. Pediatr. 56, 196 (2013). https://doi.org/10.3345/kjp.2013.56.5.196

5. K. J. Aldred, R. J. Kerns, and N. Osheroff, Biochemistry 53, 1565 (2014). https://doi.org/10.1021/bi5000564

6. M. M. Masadeh, K. H. Alzoubi, S. I. Al-Azzam, O. F. Khabour, and A. M. Al-Buhairan, Pathogens 5, 28 (2016). https://doi.org/10.3390/pathogens5010028

7. S. Correia, P. Poeta, M. Hebraud, J. L. Capelo, and G. Igrejas, J. Med. Microbiol. 66, 551 (2017). https://doi.org/10.1099/jmm.0.000475

8. D. C. Hooper and J. S. Wolfson, N. Engl. J. Med. 324, 384 (1991). https://doi.org/10.1056/NEJM199102073240606

9. M. L. Bennish, M. A. Salam, W. A. Khan, and A. M. Khan, Ann. Intern. Med. 117, 727 (1992). https://doi.org/10.7326/0003-4819-117-9-727 
10. H. A. Ludlam, I. Barton, L. White, C. Mc Mullin, A. King, and I. Phillips, J. Antimicrob. Chemother. 25, 843 (1990). https://doi.org/10.1093/jac/25.5.843

11. L. R. Peterson, L. M. Lissack, K. Canter, C. E. Fasching, C. Clabots, and D. N. Gerding, Am. J. Med. 86, 801 (1989). https://doi.org/10.1016/0002-9343(89)90476-2

12. C. Jean-Didier, R. Francoise, and G. Monique, J. Antimicrob. Chemother. 46, 2306 (2002).

13. Y. Yamashita, T. Ashizawa, M. Morimoto, J. Hosomi, and H. Nakano, Cancer Res. 52, 2818 (1992).

14. T. D. Goots and K. E. Brighty, Med. Res. Rev. 16, 433 (1996). https://doi.org/10.1002/(SICI)1098-1128(199609)16:5<433::AID-MED3>3.0.CO;2-W

15. N. J. de Souza, S. V. Gupte, P. K. Deshpande, V. N. Desai, S. B. Bhawsar, R. D. Yeole, M. C. Shukla, J. Strahilevitz, D. C. Hooper, B. Bozdogan, P. C. Appelbaum, M. R. Jacobs, N. Shetty, M. V. Patel, R. Jha, and H. F. Khorakiwala, J. Med. Chem. 48, 5232 (2005). https://doi.org/10.1021/jm050035f

16. M. G. Rabbani, M. R. Islam, and M. Ahmad, J. Bangl. Chem. Soc. 26, 30 (2013).

17. R. Siddiqui, N. Sultana, K. M. Khan, N. Akbar, M. Ali, and S. Arayne, J. Chin. Clin. Med. 2, 188 (2007).

18. S. Jubie, P. Sikdar, R. Kalirajan, B. Gowramma, S. Gomathy, S. Sankar, and K. Elango, J. Pharma. Res. 3, 511 (2010).

19. M. G. Rabbani, M. R. Islam, M. Ahmad, and A. M. L. Hossion, Bangl. J. Pharmacol. 6, 8 (2011). https://doi.org/10.3329/bjp.v6i1.7720

20. H. Ahmad, T. K. Pal, M. A. Alam, J. Hossen, S. Paul, and M. C. Sheikh, J. Sci. Res. 10, 291 (2018). https://doi.org/10.3329/jsr.v10i3.36379

21. A. Cipurković, E. Horozić, N. Ljubijankić, A. Odobašić, S. Galijašević, and M. Saletović, Rasayan J. Chem. 10, 1381 (2017).

22. N. Ljubijankić, M. Stanković, V. Tešević, S. Grgurić-Šipka, M. Jadranin, S. Begić, and E. Šabanović, Rasayan J. Chem. 11, 647 (2018). https://doi.org/10.31788/RJC.2018.1123004

23. A. Scozzafava, L. Menabuoni, and F. Mincione, Bioorg. Medic. Chem. Lett. 11, 575 (2001). https://doi.org/10.1016/S0960-894X(00)00722-8

24. A. Scozzafana and C. T. Supuran, J. Med. Chem. 43, 3677 (2000). https://doi.org/10.1021/jm000027t

25. D. J. Austin, K. G. Kristinsson, and R. M. Anderson, Proc. Natl. Acad. Sci. USA 96, 1152 (1999). https://doi.org/10.1073/pnas.96.3.1152

26. M. G. Rabbani and M. R. Islam, J. Sci. Res. 11, 351 (2019). http://dx.doi.org/10.3329/jsr.v11i3.38843

27. A. W. Bauer, W. M. M. Kirby, J. C. Sheriss, and M. Turck, Am. J. Clin. Path. 45, 493 (1966). https://doi.org/10.1093/ajcp/45.4 ts.493

28 M. H. Islam, M. C. Sheikh, and M. A. A. A. A. Islam, J. Sci. Res. 11, 121 (2019). http://dx.doi.org/10.3329/jsr.v11i1.37863

29. B. N. Meyer, N. R. Ferrigni, J. E. Putnam, L. B. Jacobsen, D. E. Nichols, and J. L. McLaughin, Planta Medica. 45, 31 (1982). https://doi.org/10.1055/s-2007-971236

30. A. K. Azad, M. A. Jainul and Z. K. Labu, J. Sci. Res. 10, 175 (2018). https://doi.org/10.3329/jsr.v10i2.34820 